\title{
Atrioventricular Block in a Patient Followed Up with a Diagnosis of Epilepsy
}

\author{
Epilepsi Tanısıyla Takip Edilen Hastada Atrioventriküler Blok
}

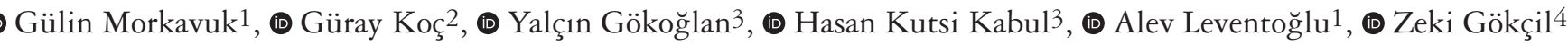

1 Ufuk University Faculty of Medicine, Department of Neurology, Ankara, Turkey

2Health Sciences University Gulhane Training and Research Hospital, Clinic of Neurology, Ankara, Turkey

3Health Sciences University Gulhane Training and Research Hospital, Clinic of Cardiology, Ankara, Turkey

4Eastern Mediterranean University Faculty of Health Sciences, Department of Physiotherapy and Rehabilitation, KKTC

Keywords: Video electroencephalographic monitoring, seizure, atrioventricular block

Anahtar Kelimeler: Video elektroensefalografi monitörizasyon, nöbet, atrioventriküler blok

\section{Dear Editor,}

Video-electroencephalographic (EEG) monitorization (VEM) refers to recording EEG and video for longer than the standard recording time. This period varies between hours, days, and weeks, with a minimum of 2 hours. The aim of VEM is to examine seizures and synchronous EEGs, classify epileptic seizures, reveal non-epileptic seizures, and identify the seizure-onset zone if the patient is a surgical candidate.

Electrocardiography (ECG) electrodes are mostly used in VEM units in EEG monitoring. The use of ECG electrodes makes it easier to distinguish pulse artifacts in the EEG and to detect arrhythmias that can occur in patients. Cardiac arrhythmias are not uncommon in patients with epilepsy. They may be interictal or peri-ictal (1). In some studies, $25 \%$ of patients thought to have epileptic seizures were claimed to be episodes of cardiac events (2). Many patients with seizure-like clinical pictures are known to be diagnosed as having epilepsy without detailed cardiologic evaluation and supporting EEG findings. Detection of arrhythmias in the ECG record in the absence of change in EEG during episodes of these conditions such as cardiogenic syncope can alter the diagnosis and treatment of the patient.

A 43-year-old woman was learned to have 20-30 seconds of seizure activity beginning five years ago with a sudden breathing sound during nighttime sleep with upward deviation of the head and eyes, accompanied by loss of consciousness. It was learned that she was diagnosed as having epilepsy in another hospital and lamotrigine treatment was initiated and different drugs were used later because of lack of seizure control. The frequency of these seizures was 2-3 times per month initially, but they gradually increased despite the use of antiepileptic treatment. It was learned that the patient first felt anxiety before some of the seizures, and then fainted after feeling poorly and that she did not lose consciousness during some other seizures. When seizure activity recorded at home was reviewed, it was determined that she had agonal respiration. The patient was admitted to the VEM unit for differential diagnosis of epilepsy. Her neurologic examination was normal. She was on 1000 $\mathrm{mg} /$ day carbamazepine and $2000 \mathrm{mg} /$ day levetiracetam at admission. The doses of the medications that the patient had been using were reduced. The seizures she described as a bad feeling were recorded 7 times during the monitorization. During these seizures, it was seen that she commented at the start of her seizures by saying she had a bad feeling and by saying, "it came, it came", that she had a worried facial expression, however, that she did not lose consciousness. At that time, there was no change except for the artifacts recorded in the EEG recordings, and it was noted that she had atrioventricular (AV) complete block with asystole on ECG. After an asystole episode lasting

Address for Correspondence/Yazışma Adresi: Gülin Morkavuk MD, Ufuk University Faculty of Medicine, Department of Neurology, Ankara, Turkey Phone: +90 3122044232 E-mail: drgcmor@yahoo.com ORCID ID: orcid.org/0000-0001-7522-8585

Received/Geliss Tarihi: 14.04.2017 Accepted/Kabul Tarihi: 18.08.2017

${ }^{\circ}$ Copyright 2018 by Turkish Neurological Society

Turkish Journal of Neurology published by Galenos Publishing House. 
approximately 10-12 seconds, it was observed that the rhythm spontaneously turned back to normal sinus rhythm but as bradycardic. During asystole, the atrial systolic p wave occurred, but the QRS wave did not occur due to an inability to transmit the transmission to the ventricle (Figure 1). Regarding these findings, the patient was referred to the cardiology department and VEM records were also reviewed by cardiologists. In all records, AV complete block was detected in the ECG tracts during periods when the patient felt poorly. It was stated that a complete syncope did not develop as normal sinus rhythm was achieved spontaneously in a short time, and that the episodes experienced by the patient developed due to intermittent AV complete block. The patient's detailed cardiologic examination was completed by additional echocardiography and Holter ECG monitoring examinations. The patient underwent permanent DDDR pacemaker implantation. Meanwhile, treatment with levetiracetam $2000 \mathrm{mg} /$ day was continued. The seizures did not repeat after pacemaker implantation.

It is known that epilepsy treatment can be initiated in many patients with a seizure-like clinical picture without detailed cardiac research. VEM is an important guide in distinguishing paroxysmal events from epileptic seizures. In our patient, who had been followed up with a diagnosis of epilepsy for five years, VEM was used to make the diagnosis of complete AV block and a pacemaker was implanted, and the patient was able to continue her life seizure-free.

The most common cause of cardiac syncope is arrhythmias such as severe sinus bradycardia $(<40 / \mathrm{min})$, sinoatrial block or sinus pause $>3 \mathrm{sec}$, AV complete block, intermittent AV block and continuous ventricular tachycardia. Apart from arrhythmic causes, cardiovascular diseases such as aortic valve stenosis, hypertrophic cardiomyopathy, atrial myxoma, pulmonary embolism, and myocardial infarction may cause syncope as a result of decreased

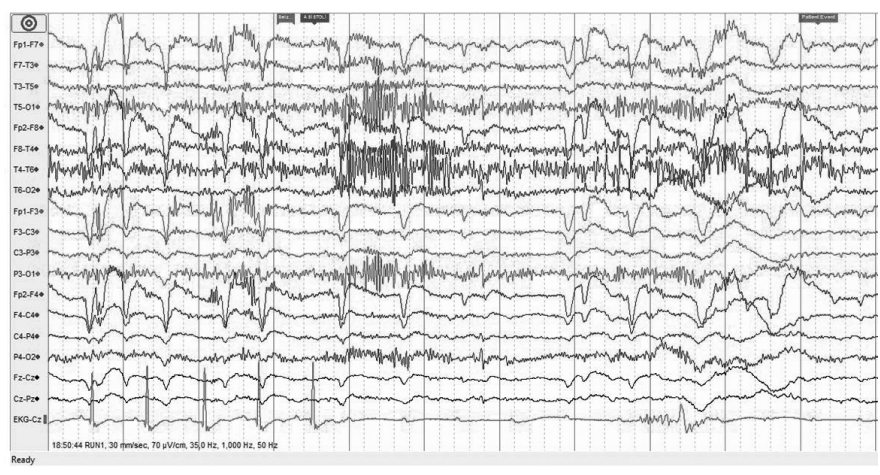

Figure 1. Asystole starts in electrocardiography (ECG) recording, no changes other than artifacts in electroencephalographic recording. P-wave activity continues in ECG recording. cardiac output. Cardiac syncope occurs more frequently in patients with complete AV block and heart rhythm $\leq 40 / \mathrm{min}$.

Long QT syndrome is one of the causes of syncope that should be considered in the differential diagnosis of epilepsy. This syndrome is a clinically and genetically heterogeneous syndrome with ventricular arrhythmias with prolonged QT in ECG that cause a tendency to ventricular fibrillation and Torsade de pointes $(3,4)$. In a study performed in Turkey, ECG recording was performed during routine EEG and arrhythmia was detected in 48 of 2136 subjects. Long QT was detected in 5 of these 48 patients (5).

VEM is an important diagnostic tool for the classification of seizures, identifying the seizure-onset zone if the patient is a surgical candidate, and identification of non-epileptic seizures. Its role in the definite diagnosis of non-epileptic seizures is especially important. The definite diagnosis of seizure ensures that the patient's symptoms are reduced, that the drug load is reduced, and the risk to the life of the patient is completely eliminated by cardiac pacemaker implantation, as is sometimes the case with the cardiac pathologies. In conclusion, as well as a good history, neurologic examination, and routine EEG monitoring.

Ethics

Informed Consent: Consent form was filled out by all participants.

Peer-review: Internally peer-reviewed.

\section{Authorship Contributions}

Surgical and Medical Practices: G.M., G.K., H.K.K., Y.G, A.L., Z.G., Concept: G.M., G.K., Design: G.M., G.K., Data Collection or Processing: G.M., G.K., H.K.K., Y.G., Analysis or Interpretation: G.M., G.K., A.L., Z.G., Literature Search: G.M., G.K., Writing: G.M.

Conflict of Interest: No conflict of interest was declared by the authors.

Financial Disclosure: The authors declared that this study received no financial support.

\section{References}

1. Rugg-Gunn FJ, Simister RJ, Squirrell M, Holdright DR, Duncan JS. Cardiac arrhythmias in focal epilepsy: a prospective longterm study. Lancet 2004;364:2212-2219.

2. Zaidi A, Clough P, Cooper P, Scheepers B, Fitzpatrick AP. Misdiagnosis of epilepsy: many seizure-like attacks have a cardiovascular cause. J Am Coll Cardiol 2000;36:181-184

3. Hunter JD, Sharma P, Rathi S. Long QT syndrome. Contin Educ Anaesth Crit Care Pain 2008;8:67-70.

4. Rocamora R, Kurthen M, Lickfett L, Von Oertzen J, Elger CE. Cardiac asystole in epilepsy: clinical and neurophysiologic features. Epilepsia 2003;44:179-185.

5. Önder H, Tezer Fİ, Sayg 1 S. Rutin EEG Kaydı Sırasında Eş Zamanlı EKG’nin Önemi. Epilepsi 2013;19:19-23. 